\title{
Penggunaan Pembelajaran STAD dalam Meningkatkan Kemampuan Berpikir Kritis Siswa Kelas IV SD
}

\author{
Siti Barokah ${ }^{1}$ Badarudin $^{2}$ Karma Iswasta Eka ${ }^{3}$ \\ ${ }^{123}$ Program Studi Pendidikan guru Sekolah dasar, \\ Universitas Muhammadiyah Purwokerto, \\ Purwokerto, Indonesia \\ e-mail: sitibarokah2012@gmail.com ${ }^{1}$, badarudinbdg@gmail.com², \\ eka2001id@gmail.com ${ }^{3}$
}

\begin{abstract}
Abstrak
Hasil belajar siswa di kelas IV SD Negeri 1 Bulakamba masih rendah, hal ini dapat dilihat dari kemampuan siswa untuk menyelesaikan soal Matematika pada materi keliling dan luas bangun datar. STAD merupakan sebuah strategi pembelajaran yang menuntun siswa untuk dapat bekerja sama, memiliki tanggung jawab, dan mampu menyampaikan pendapat. Penelitian ini bertujuan untuk mengetahui peningkatan kemampuan berfikir kritis siswa dalam pembelajaran keliling dan luas bangun datar melalui pembelajaran STAD di kelas IV Sekolah Dasar, Kabupaten Brebes. Penelitian ini menggunakan metode penelitian tindakan kelas dan subjek penelitian adalah siswa kelas IV di sekolah dasar negeri Kabupaten Brebes, sebanyak 18 orang. Alat pengumpulan data dalam penelitian ini menggunakan lembar observasi, skala penilaian rubrik, soal evaluasi dan dokumentasi. Data hasil penelitian dianalisis secara deskriptif dengan melihat nilai rata-rata. Hasil penelitian dengan menggunakan pembelajaran STAD diperoleh hasil belajar sebagai berikut: pada siklus I peningkatan hasil belajar siswa sebesar $55,5 \%$, meningkat pada siklus II menjadi $83,3 \%$.
\end{abstract}

Kata Kunci: berfikir kritis, bangun datar, STAD

\begin{abstract}
Students' learning outcomes in class IV SD Negeri 1 Bulakamba were still low; this could be seen from the ability of students to solve math problems on the circumference and area of plane figure. STAD was a learning strategy that guided students to work together, had responsibilities, and be able to express opinions. The aim of this research was to know the improvement of students' critical thinking ability in learning circumference and area of plane figure through STAD on $4^{\text {th }}$ grade elementary students of SD Negeri 1 Bulakamba in Brebes regency. This research used a classroom action research and the research subjects were grade IV students in elementary school, Brebes Regency, as many as 18 students. Data collection in this research used observation sheets, scale of assessment rubric, evaluation test and documentation. The result of the research was analyzed by using descriptive analysis in the mean score. The results of this research obtained learning outcomes showed that on the first cycle, the students' learning outcomes was $55.5 \%$ and improved on the second cycle to $83,3 \%$.
\end{abstract}

Keywords: critical thinking, plane figure, STAD

\footnotetext{
${ }^{*}$ Corresponding author.

Received 20 January 2020, Accepted 20 March 2020; Available online 5 Appril 2020 (C) 2020 MI All Rights Reserved
} 


\section{Pendahuluan}

Upaya peningkatan mutu pendidikan perlu dilakukan secara menyeluruh meliputi aspek pengetahuan, keterampilan, sikap, dan nilai-nilai pancasila. Pengembangan aspek-aspek tersebut dilakukan untuk meningkatkan dan pengembangan kecakapan hidup yang diwujudkan melalui seperangkat kompetensi. Hal ini dimaksudkan agar siswa dapat bertahan hidup serta dapat menyesuaikan diri dan berhasil dalam kehidupan di masa yang akan datang. Untuk itu sekolah diharapkan dapat untuk mewujudkan tujuan pendidikan nasional tersebut. Salah satu pelajaran yang penting di Sekolah Dasar adalah matematika, pelajaran ini nantinya sangat diperlukan dalam kehidupan sehari-hari.

Matematika merupakan suatu bahan kajian yang memiliki objek abstrak dan dibangun melalui proses penalaran deduktif, yaitu kebenaran suatu konsep diperoleh sebagai akibat logis dari kebenaran sebelumnya sehingga keterkaitan antar konsep dalam Matematika bersifat sangat kuat dan jelas. Hal itu senada dengan pendapat Heruman (2007:2) "Konsep-konsep pada kurikulum Matematika di SD dapat dibagi menjadi tiga kelompok dasar, yaitu penanaman konsep dasar (penanaman konsep), pemahaman konsep, pembinaan keterampilan". Dengan adanya ketiga unsur tersebut sehingga bahan kajian yang dibangun melalui penalaran deduktif menimbulkan keterkaitan antar konsep Matematika.

Berdasarkan kurikulum sekolah dasar yang berlandaskan tingkat satuan pendidikan, salah satu dari standar kompetensi pembelajaran Matematika yaitu menggunakan konsep keliling dan luas bangun datar sederhana dalam pemecahan masalah. Pembelajaran ini menuntut siswa untuk dapat berpikir kritis terhadap permasalahan yang timbul baik permasalahan yang disajikan dalam matematika maupun kehidupan sehari-hari. Oleh karena itu diharapkan siswa harus memiliki kecakapan khusus (kemampuan berfikir secara rasional, logis sistematis dan kritis) dalam memecahkan soal-soal, yang kelak akan diterapkan dalam memecahkan masalah yang terjadi di kehidupannya.

Setelah penulis melakukan observasi di kelas IV SD Negeri 1 Bulakamba, Kab. Brebes terdapat permasalahan-permasalahan yang memerlukan penanganan secara cepat. Permasalahan yang timbul antara lain: memberikan pembelajaran yang tidak menitik beratkan kepada pemahaman siswa untuk berfikir secara kritis terhadap suatu permasalahan, penyampaian materi yang dilakukan secara monoton, serta cara guru mengemas pembelajaran yang kurang menarik dan menyenangkan karena tidak adanya penerapan suatu model pembelajaran.

Sebaiknya dalam proses pembelajaran guru harus lebih kreatif dalam menentukan metode apa yang akan diterapkan dalam pembelajaran dan dituntut untuk lebih profesional dalam memilih pendekatan yang tepat untuk melaksanakan pembelajaran, maka masalah ini harus ditangani dengan mencari model pembelajaran yang tepat dan sesuai dengan materi yang diajarkan. Guru sebagai pengajar dan fasilitator harus mampu melakukan pembelajaran yang menyenangkan, menggairahkan sehingga akan diperoleh hasil yang maksimal. Kenyataan selama ini kegiatan belajar mengajar masih didominasi guru yaitu kegiatan satu arah dimana penuangan informasi dari guru ke siswa dan hanya dilaksanakan dan berlangsung di sekolah, sehingga hasil yang dicapai siswa hanya mampu menghafal fakta, konsep, prinsip, hukum-hukum, teori hanya pada tingkat ingatkan.

Upaya yang harus dilakukan untuk memulai tuntutan lulusan yang kompetitif di era pembangunan yang berbasis ekonomi dan globalisasi adalah menyelaraskan kegiatan pembelajaran dengan nuansa Kurikulum Tahun 2013 (KURTILAS) yang diindikasikan dengan keterlibatan siswa secara aktif dalam membangun gagasan atau pengetahuan oleh masingmasing individu baik di dalam maupun diluar lingkungan sekolah. Salah satu diantaranya adalah model Student Team Achievement Division dengan pembelajaran model Student Team 
Achievement Division (STAD) diharapkan siswa dapat menggali dan menemukan pokok materi secara bersama-sama dalam kelompok atau secara individu. Penerapan model Student Team Achievement Division (STAD) merupakan tindakan pemecahan masalah yang ditetapkan dalam upaya meningkatkan kemampuan berfikir kritis dalam pembelajaran keliling dan luas bangun datar sederhana pada siswa kelas IV SD Negeri 1 Bulakamba Kab. Brebes.

\section{Metode}

Penelitian tindakan kelas ini dilaksanakan dengan dua siklus, dan tiap siklus terdiri dari empat tahapan, yaitu: membuat perencanaan, pelaksanaan, observasi, refleksi. Subjek penelitian ini adalah siswa kelas IV SD Negeri 1 Bulakamba Tahun Ajaran 2019/2020 dengan jumlah siswa sebanyak 18 orang yang masing-masing terdiri dari 8 orang laki-laki dan 10 orang perempuan. Umur antara 9-10 tahun. Sebagian dari jumlah siswa berasal dari latar belakang ekonomi golongan sedang dan tinggi dengan pekerjaan orang tua antara lain: petani, pedagang, pegawai negeri, dan wiraswasta. Dengan latar belakang pendidikan orang tua tidak sekolah, tamatan SD, SMP dan SLTA.

Metode pengumpulan data, yaitu metode tes dan observasi. Tes evaluasi adalah suatu cara untuk mengadakan penilaian yang berbentuk suatu tugas atau serangkaian tugas yang harus dikerjakan oleh anak atau sekelompok anak sehingga menghasilkan suatu nilai tentang tingkah laku atau prestasi anak tersebut, yang dapat dibandingkan dengan nilai yang dicapai oleh anak-anak lain atau dengan nilai standar yang ditetapkan (Nurkancana dan Sunartana, 1990: 34). Observasi adalah suatu cara untuk mengadakan penilaian dengan jalan mengadakan pengamatan secara langsung dan sistematis. Data-data yang diperoleh dalam observasi itu dicatat dalam suatu catatan observasi. Kegiatan pencatatan dalam hal ini adalah merupakan bagian dari kegiatan pengamatan.

Analisis data dalam penelitian ini yaitu analisis data hasil belajar siswa yang dilakukan dengan kegiatan pengolahan data. Metode analisis data yang digunakan dalam penelitian ini adalah metode statistik deskriptif. Sugiyono (2013: 207) menyatakan statistik deskriptif adalah statistik yang digunakan untuk menganalisis data yang telah terkumpul sebagaimana adanya tanpa bermaksud membuat kesimpulan yang berlaku untuk umum atau generalisasi. Metode statistik deskriptif digunakan untuk mengolah data tes dan data observasi.

\section{Hasil dan Pembahasan}

\section{Siklus I}

Penelitian pada siklus I ini dilaksanakan pada tiga kali pertemuan yaitu tanggal 14 Januari 2020 pada jam pelajaran kesatu dan kedua, tanggal 15 Januari 2020 pada jam pelajaran kesatu dan kedua dan 17 Januari 2020 pada jam pelajaran kesatu dan kedua. Rencana tindakan pembelajaran diberikan waktu tiga kali pertemuan ( 6 × 35 menit).

Perencanaan Tindakan Siklus I. 1) Menyusun Rencana Pelaksanaan Pembelajaran (RPP) tindakan untuk siklus pertama penelitian. 2) Membuat alat observasi kelas untuk mengumpulkan data penelitian. Alat observasi disesuaikan dengan indikator data yang berhubungan dengan perbaikan proses pembelajaran. 3) Pengadaan media pembelajaran yang sesuai dengan topik atau tema pembelajaran dan materi sewaktu penelitian. 4) Membuat alat evaluasi berupa soal latihan untuk mengetahui hasil belajar siswa pada pertemuan pertama sampai pertemuan ketiga pada siklus I.

Pelaksanaan tindakan yang dilakukan adalah sesuai dengan judul penelitian tindakan ini adalah meningkatkan kemampuan berfikir kritis dalam pembelajaran keliling dan luas bangun datar melalui metode STAD kelas IV SD Negeri 1 Bulakamba dimana secara umum skenario 
tindakan pada meliputi: 1) Guru melakukan apersepsi dengan meninjau kembali materi yang pernah dipelajari sebelumnya, yang berkaitan dengan bangun datar dengan tujuan mengingatkan pikiran siswa terhadap pembelajaran yang pernah dilaluinya, kemudian menjelaskan tujuan pembelajaran dari materi yang akan dipelajari diharapkan siswa dapat menentukan keliling dan luas jajar genjang dan segitiga, selanjutnya guru memberikan motivasi kepada siswa tentang materi yang akan diajarkan. Pada daur ini guru memulai pembelajaran dengan membagi siswa dalam beberapa kelompok yang terdiri dari 4 orang yang dipilih secara heterogen (prestasi, jenis kelamin, suku), guru menekankan kepada siswa bahwa setiap siswa mempunyai tanggung jawab terhadap materi yang diberikan dan nilai yang diperolehnya akan menjadi skor kelompoknya. 2) Guru menjelaskan materi pecahan secara garis besar, selanjutnya siswa diminta untuk memahami materi pada buku siswa yang telah dibagikan, dalam kerja kelompok ini siswa saling berbagi tugas, saling membantu menyelesaikan tugas dengan target mampu memahami materi secara benar. Salah satu lembar kerja dikumpulkan sebagai hasil kerja kelompok siswa. Guru memberikan tes individual (kuis), tujuannya agar siswa dapat menunjukkan pemahaman tentang apa yang telah dipelajarinya. Di kegiatan akhir guru menghitung skor masing-masing siswa dan membahagiakan kepada siswa. melakukan tanya jawab tentang materi yang belum dipahami dan bersama siswa menyimpulkan pembelajaran.

Untuk meningkatkan kemampuan berfikir kritis siswa dalam materi keliling dan luas bangun datar sederhana, kegiatan yang dilakukan guru dan siswa sebagai berikut: 1) Siswa memahami materi yang telah disampaikan, sebab setiap siswa bertanggung jawab terhadap kelompoknya, artinya skor setiap siswa akan menjadi skor kelompoknya. 2) Jika siswa belum mengerti menanyakan kepada teman satu kelompok. 3) Siswa bertanya pada guru jika terdapat soal yang tidak dapat dijawab atau materi yang masih belum mengerti. 4) Siswa bertanya jawab dengan guru tentang pembelajaran yang masih belum dipahami. 4) Menyimpulkan pembelajaran.

Kegiatan observasi yang dilakukan pada tindakan ini sesuai dengan instrumen berupa lembar observasi yang mengukur kegiatan guru, kemampuan berfikir kritis siswa, dan hasil belajar siswa. Untuk melihat hasil observasi kegiatan guru dapat dilihat pada tabel 1 dibawah ini:

Tabel 01 Hasil Observasi Kegiatan Guru pada Siklus I

\begin{tabular}{cccccc}
\hline \multirow{2}{*}{ Kegiatan Siklus I } & \multicolumn{3}{c}{ Skor yang diperoleh } & \multirow{3}{*}{ Jumlah } & (\%) \\
\cline { 2 - 4 } & \multicolumn{3}{c}{ Pertemuan } & & \\
\cline { 2 - 4 } & & I & II & III & \\
\hline Jumlah & 22 & 27 & 31 & 80 \\
\hline Presentase & 42 & 52 & 59,5 & 51,2 \\
\hline
\end{tabular}

Berdasarka tabel 1 di atas dapat diketahui bahwa kegiatan guru dalam melaksanakan metode STAD dalam proses pembelajaran pada siklus I, guru melaksanakannya masih kurang sekali, terlihat dari pertemuan 1 persentasenya hanya $42 \%$, sedang dipertemuan kedua hanya mencapai $52 \%$ dan pertemuan ke 3 hanya 59,5\% dengan kategori kurang. Sementara persentase kegiatan guru dalam menerapkan metode STAD pada siklus I hanya $51,2 \%$. Selanjutnya untuk melihat kemampuan berfikir kritis siswa pada siklus I dapat dilihat pada tabel 2 dibawah ini: 
Tabel 02 Hasil Observasi Kemampuan Berfikir Kritis Siswa Siklus

\begin{tabular}{|c|c|c|c|c|c|c|c|c|c|}
\hline \multirow[t]{2}{*}{ No } & \multirow{2}{*}{$\begin{array}{l}\text { Indikator } \\
\text { Pengamatan }\end{array}$} & \multicolumn{2}{|c|}{ P1 } & \multicolumn{2}{|l|}{ P2 } & \multicolumn{2}{|l|}{ P3 } & \multicolumn{2}{|c|}{ Rata-rata } \\
\hline & & $\mathbf{F}$ & $\%$ & $\mathbf{F}$ & $\%$ & $\mathbf{F}$ & $\%$ & $\mathbf{F}$ & $\%$ \\
\hline 1 & $\begin{array}{l}\text { Kemampuan } \\
\text { mengajukan } \\
\text { pertanyaan yang } \\
\text { banyak dan tepat }\end{array}$ & 40 & 55,5 & 45 & 62,5 & 50 & 69,4 & 135 & 62,5 \\
\hline 2 & $\begin{array}{l}\text { Kemampuan } \\
\text { menggali informasi }\end{array}$ & 48 & 66,6 & 49 & 68 & 50 & 69,4 & 147 & 68,5 \\
\hline 3 & $\begin{array}{l}\text { Kemampuan } \\
\text { mengatakan } \\
\text { pendapat dengan } \\
\text { menyertakan } \\
\text { alasan atau } \\
\text { perbandingan }\end{array}$ & 38 & 52,7 & 41 & 56,9 & 40 & 55,5 & 119 & 55 \\
\hline 4 & $\begin{array}{l}\text { Kemampuan } \\
\text { menyajikan data } \\
\text { secara mendetail }\end{array}$ & 48 & 66,6 & 51 & 70,8 & 55 & 76,3 & 154 & 71,2 \\
\hline 5 & $\begin{array}{l}\text { Kemampuan } \\
\text { memberikan } \\
\text { interpretasi secara } \\
\text { logis terhadap } \\
\text { permasalahan } \\
\text { yang ada }\end{array}$ & 38 & 52,7 & 44 & 61,1 & 43 & 59,7 & 125 & 57,8 \\
\hline 6 & $\begin{array}{l}\text { Kemampuan } \\
\text { menunjukkan } \\
\text { perbedaan dua hal }\end{array}$ & 41 & 56,9 & 46 & 63,8 & 42 & 58,3 & 129 & 59,7 \\
\hline 7 & $\begin{array}{l}\text { Kemampuan } \\
\text { mengemukakan } \\
\text { ide }\end{array}$ & 43 & 59,7 & 54 & 75 & 49 & 68 & 146 & 67,5 \\
\hline 8 & $\begin{array}{l}\text { Kemampuan } \\
\text { menunjukkan } \\
\text { masalah }\end{array}$ & 41 & 56,9 & 45 & 62,5 & 45 & 63,5 & 131 & 60,6 \\
\hline
\end{tabular}




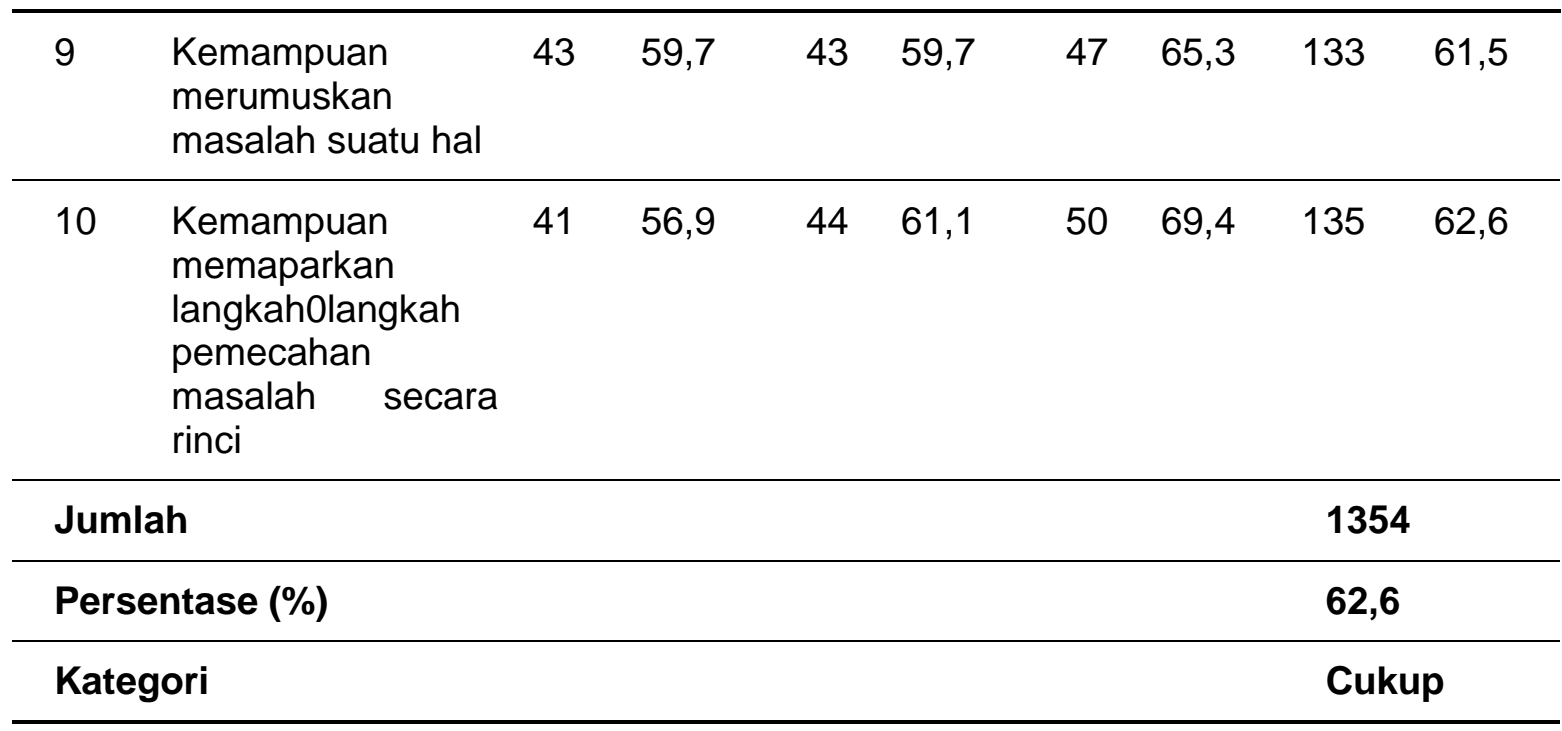

Berdasarkan tabel 2 di atas pada pembelajaran keliling dan luas bangun datar sederhana siklus I dapat dilihat bahwa setiap indikator kemampuan berfikir kritis siswa hanya tiga indikator yang telah mencapai standar ketuntasan dan tujuh indikator lainnya belum mencapai standar ketuntasan dengan rata-rata 62,6. Selain kemampuan berfikir kritis siswa yang diamati hasil belajar siswa juga dinilai sebagai hasil pembelajaran yang diteliti pada materi keliling dan luas bangun datar sederhana dengan menggunakan metode STAD. Dapat dilihat hasil belajar siswa pada siklus I dalam tabel 3 dibawah ini:

Tabel 03 Nilai Hasil Belajar Siswa Siklus I

\begin{tabular}{|c|c|c|c|c|c|c|c|c|}
\hline \multirow{2}{*}{ No } & \multirow{2}{*}{$\begin{array}{l}\text { Nama } \\
\text { Siswa }\end{array}$} & \multicolumn{3}{|c|}{ SIKLUS HASIL } & \multirow{2}{*}{ JUMLAH } & \multirow{2}{*}{$\begin{array}{l}\text { Rata- } \\
\text { rata }\end{array}$} & \multicolumn{2}{|c|}{ Ketuntasan } \\
\hline & & P1 & P2 & P3 & & & Ya & Tdk \\
\hline & \multicolumn{3}{|c|}{ Jumlah } & & 3605 & & 10 & 8 \\
\hline & \multicolumn{3}{|c|}{ Rata-rata } & & 66,7 & & & \\
\hline & \multicolumn{3}{|c|}{ Persentase Ketuntasan } & & & & 55,5 & 44,5 \\
\hline & \multicolumn{3}{|c|}{ Kategori } & & \multicolumn{4}{|c|}{ Sebagian Besar } \\
\hline
\end{tabular}

Berdasarkan tabel 3 di atas dapat dilihat bahwa rata-rata hasil belajar siswa secara klasikal hanya naik sedikit dari standar ketuntasan 65 , dari tabel hanya terlihat 66,7 sedangkan persentase ketuntasan individu hanya $55,5 \%$ artinya hanya sebagian besar yang telah mencapai ketuntasan sebagian yang lain belum mencapai standar ketuntasan. Hal ini menunjukkan bahwa pembelajaran belum berhasil perlu dievaluasi untuk siklus II.

Berdasarkan hasil belajar siswa pada siklus I yang tercantum pada tabel 3 dengan materi keliling dan luas bangun datar sederhana dapat disimpulkan sebagai berikut: 1) Dari 18 siswa yang memperoleh nilai 65 atau lebih sebanyak 10 orang dengan ketuntasan 55,5\%. 2) Siswa yang memperoleh nilai kurang dari 65 adalah sebanyak 8 orang dari 18 siswa atau tidak 
tuntas $44,4 \%$ dari data keseluruhan diperoleh nilai rata-rata 66,7. 3) Hasil belajar siswa pada siklus I belum memuaskan karena rata-rata hasil belajar secara klasikal hanya naik 1,7 maka harus direvisi untuk siklus II.

Kesulitan yang dialami siswa: Tak jarang sebagian siswa berlaku tidak sportif pada salah satu temannya memberikan pendapat atau menjawab pertanyaan dari guru yakni dengan mengejek atau mencemooh siswa yang sedang berbicara. 1) Sebagian siswa masih ada yang belum terlalu paham mengenai materi keliling dan luas bangun datar sederhana dikarenakan kurangnya keseriusan siswa menerima penjelasan materi dari guru. 2) Pada saat pelaksanaan penerapan metode STAD keadaan kelas kurang terkontrol sehingga tercipta suasana yang ribut, karena kurangnya pemahaman siswa terhadap pembelajaran dengan metode STAD. 3) Masih sedikit siswa yang melakukan kerjasama dengan teman-temannya, dikarenakan siswa masih saja mementingkan individualis. 4) Pada saat pembelajaran masih banyak siswa yang tidak mengeluarkan pendapat atau pemikirannya dikarenakan siswa masih merasa canggung dan takut untuk menyampaikan pendapatnya.

Berdasarkan hasil observasi dan hasil belajar siswa, maka perlu dilakukannya revisi pada siklus II yaitu dengan : 1) Guru akan memberikan penjelasan tentang pelaksanaan pembelajaran dengan metode STAD, dimana siswa bertanggung jawab terhadap dirinya dan kelompoknya. Kerjasama disini di maksud untuk mengeratkan hubungan antar siswa khususnya pada saat mengalami kesulitan dalam belajar siswa dapat bertanya pada temannya yang telah mengerti atau menyampaikan pendapatnya dengan teman lainnya. 2) Guru akan mencoba melakukan pendekatan yang lebih lagi terhadap siswa, serta memberikan rasa nyaman pada siswa untuk selalu berkomunikasi atau berinteraksi dengan guru pada saat proses pembelajaran berlangsung sehingga siswa berani menyampaikan pendapatnya. 3) Guru akan memberikan pengertian pada siswa yang terbiasa mencemooh teman pada saat berbicara didepan kelas, bahwa tidak baik melakukan hal tersebut karena belum tentu kita yang mengejek teman bisa lebih baik dari teman yang sedang mengutarakan pendapatnya di depan kelas, jadi hendaknya didalam berteman harus saling menghargai dan bersikap sportif. 4) Guru akan meningkatkan cara menjelaskan materi keliling dan luas bangun datar sederhana kepada siswa dan berusaha membuat pembelajaran lebih menarik lagi yakni dibantu dengan penerapan metode STAD secara lebih tepat dan alat bantu yang lebih menarik.

\section{Siklus II}

Penelitian pada siklus II ini dilaksanakan pada tiga kali pertemuan yaitu tanggal 21 Januari 2020 pada jam kesatu dan kedua, tanggal 22 Januari 2020 pada jam kesatu dan kedua dan 24 Januari 2020 pada jam kesatu dan kedua, rencana tindakan pembelajaran diberikan waktu tiga kali pertemuan ( $6 \times 35$ menit).

Perencanaan Tindakan Siklus II. 1) Rencana Pelaksanaan Pembelajaran (RPP) tindakan untuk siklus pertama penelitian. 2) Membuat alat observasi kelas untuk mengumpulkan data penelitian. Alat observasi disesuaikan dengan indikator data yang berhubungan dengan perbaikan proses pembelajaran. 3) Pengadaan media pembelajaran yang sesuai dengan topik atau tema pembelajaran dan materi sewaktu penelitian. 4) Membuat alat evaluasi berupa soal latihan untuk mengetahui hasil belajar siswa pada pertemuan pertama sampai pertemuan ketiga pada siklus II.

Pelaksanaan tindakan yang dilakukan adalah sesuai dengan judul penelitian tindakan ini adalah meningkatkan kemampuan berfikir kritis dalam pembelajaran keliling dan luas bangun datar melalui metode STAD kelas IV SD Negeri 1 Bulakamba dimana secara umum skenario tindakan pada meliputi: 1) Guru melakukan apersepsi dengan meninjau kembali materi yang dipelajari sebelumnya, tentang keliling dan luas segitiga dan jajargenjang dengan tujuan meningkatkan pikiran siswa terhadap pembelajaran yang yang pernah dilaluinya, kemudian 
menjelaskan tujuan pembelajaran dari materi yang akan dipelajari diharapkan siswa dapat menentukan keliling dan luas jajargenjang dan segitiga, selanjutnya guru memberikan motivasi kepada siswa tentang materi yang diajarkan. Pada daur ini guru memulai pembelajaran dengan membagi siswa dalam beberapa kelompok yang terdiri dari 4 orang yang dipilih secara heterogen (prestasi, jenis kelamin, suku), guru menekankan kepada siswa bahwa setiap siswa mempunyai tanggung jawab terhadap materi yang diberikan dan nilai yang diperolehnya akan menjadi skor kelompoknya. Guru menjelaskan materi pecahan secara garis besar, selanjutnya siswa memahami materi tersebut, saling bantu menyelesaikan tugas dengan target mampu memahami materi masing-masing secara benar. Salah satu kerja dikumpulkan sebagai hasil kerja kelompok siswa. guru memberikan tes individual (kuis), tujuannya agar siswa dapat menunjukkan pemahaman tentang apa yang telah dipelajarinya. Di kegiatan akhir guru menghitung skor masing-masing siswa dan membagikan kepada siswa. Melakukan tanya jawab tentang materi yang belum dipahami dan bersama siswa menyimpulkan pembelajaran.

Untuk meningkatkan kemampuan berfikir kritis siswa dalam materi keliling dan luas bangun datar sederhana, kegiatan yang dilakukan guru dan siswa sebagai berikut: 1) Siswa memahami materi yang telah dibagikan, sebab setiap siswa bertanggung jawab terhadap kelompoknya, artinya skor setiap siswa akan menjadi skor kelompoknya. 2) Jika siswa belum mengerti menanyakan kepada teman satu kelompok. 3) Siswa bertanya kepada guru jika terdapat soal yang tidak dapat dijawab atau materi yang masih belum dimengerti. 4) Siswa bertanya jawab dengan guru tentang pembelajaran yang masih belum dipahami. 5) Menyimpulkan pembelajaran.

Kegiatan observasi yang dilakukan pada tindakan ini sesuai dengan instrumen berupa lembar observasi yang mengukur kegiatan guru, lembar observasi kemampuan berfikir kritis siswa, dan hasil belajar siswa. Untuk melihat hasil observasi kegiatan guru dalam pembelajaran pemecahan dengan metode STAD pada siklus II dapat dilihat pada tabel 4 dibawah ini:

Tabel 04 Hasil Observasi Kegiatan Guru pada Siklus II

\begin{tabular}{cccccc}
\hline & \multicolumn{4}{c}{ Skor yang diperoleh } & \\
\cline { 2 - 4 } Kegiatan Siklus II & \multicolumn{3}{c}{ Pertemuan } & \multirow{2}{*}{ Jumlah } & (\%) \\
\cline { 2 - 4 } & I & II & III & \\
\hline Jumlah & 43 & 46 & 49 & 140 \\
\hline Presentase & 82,6 & 88,4 & 94,2 & 89,7 \\
\hline
\end{tabular}

Berdasarkan tabel 4 diatas dapat diketahui bahwa kegiatan guru dalam melaksanakan metode STAD dalam pembelajaran keliling dan luas bangun datar sederhana pada siklus II, guru melaksanakannya sangat baik, terlihat dari pertemuan 1 persentasenya mencapai $82,69 \%$, semakin meningkat dipertemuan kedua mencapai $88,64 \%$ dan semakin bagus pada pertemuan ketiga dengan persentase $94,23 \%$. Sementara persentase ketuntasan kegiatan guru dalam menerapkan metode STAD pada siklus II semakin meningkat dengan persentase $89,7 \%$. Untuk melihat hasil observasi kemampuan berfikir kritis siswa dalam pembelajaran keliling dan luas bangun datar sederhana dapat dilihat pada tabel 5 dibawah ini: 
Tabel 05 Hasil Observasi Kemampuan Berfikir Kritis Siswa Siklus II

\begin{tabular}{|c|c|c|c|c|c|c|c|c|c|}
\hline \multirow{2}{*}{ No } & \multirow{2}{*}{$\begin{array}{c}\text { Indikator } \\
\text { Pengamatan }\end{array}$} & \multicolumn{2}{|c|}{ P1 } & \multicolumn{2}{|c|}{ P2 } & \multicolumn{2}{|c|}{ P3 } & \multicolumn{2}{|c|}{ Rata-rata } \\
\hline & & $\mathbf{F}$ & $\%$ & $\mathbf{F}$ & $\%$ & $\mathbf{F}$ & $\%$ & $\mathbf{F}$ & $\%$ \\
\hline 1 & $\begin{array}{l}\text { Kemampuan } \\
\text { mengajukan } \\
\text { pertanyaan yang } \\
\text { banyak dan tepat }\end{array}$ & 58 & 80,5 & 60 & 83,3 & 62 & 86,1 & 180 & 83,3 \\
\hline 2 & $\begin{array}{l}\text { Kemampuan } \\
\text { menggali informasi }\end{array}$ & 63 & 87,5 & 65 & 90,2 & 64 & 88,8 & 192 & 88,8 \\
\hline 3 & $\begin{array}{l}\text { Kemampuan } \\
\text { mengatakan } \\
\text { pendapat dengan } \\
\text { menyertakan alasan } \\
\text { atau perbandingan }\end{array}$ & 56 & 77,7 & 56 & 77,7 & 58 & 80,5 & 170 & 78,7 \\
\hline 4 & $\begin{array}{l}\text { Kemampuan } \\
\text { menyajikan data } \\
\text { secara mendetail }\end{array}$ & 59 & 81,9 & 63 & 87,5 & 63 & 87,5 & 185 & 85,6 \\
\hline 5 & $\begin{array}{l}\text { Kemampuan } \\
\text { memberikan } \\
\text { interpretasi secara } \\
\text { logis terhadap } \\
\text { permasalahan yang } \\
\text { ada }\end{array}$ & 58 & 80,5 & 56 & 77,7 & 56 & 77,7 & 170 & 78,7 \\
\hline 6 & $\begin{array}{l}\text { Kemampuan } \\
\text { menunjukkan } \\
\text { perbedaan dua hal }\end{array}$ & 59 & 81,9 & 56 & 77,7 & 59 & 81,9 & 174 & 80,5 \\
\hline 7 & $\begin{array}{l}\text { Kemampuan } \\
\text { mengemukakan ide }\end{array}$ & 57 & 79,1 & 59 & 81,9 & 57 & 79,1 & 173 & 80 \\
\hline 8 & $\begin{array}{l}\text { Kemampuan } \\
\text { menunjukkan } \\
\text { masalah }\end{array}$ & 56 & 77,7 & 57 & 79,1 & 59 & 81,9 & 172 & 79,6 \\
\hline 9 & $\begin{array}{l}\text { Kemampuan } \\
\text { merumuskan }\end{array}$ & 55 & 76,3 & 56 & 77,7 & 59 & 81,9 & 170 & 78,7 \\
\hline
\end{tabular}




\begin{tabular}{|c|c|c|c|c|c|c|c|c|c|}
\hline & masalah suatu ha & & & & & & & & \\
\hline 10 & $\begin{array}{l}\text { Kemampuan } \\
\text { memaparkan } \\
\text { langkah0langkah } \\
\text { pemecahan } \\
\text { masalah secara } \\
\text { rinci }\end{array}$ & 58 & 80,5 & 62 & 86,1 & 60 & 83,3 & 180 & 83,3 \\
\hline \multicolumn{6}{|c|}{ Jumlah } & \multicolumn{4}{|c|}{1766} \\
\hline \multicolumn{6}{|c|}{ Persentase (\%) } & \multicolumn{4}{|c|}{81,7} \\
\hline \multicolumn{8}{|c|}{ Kategori } & & 3aik \\
\hline
\end{tabular}

Berdasarkan tabel 5 diatas terlihat kemampuan berfikir kritis siswa telah meningkat dengan baik dan telah melebihi standar ketuntasan yang telah ditetapkan dengan persentase $81,7 \%$. Untuk melihat hasil belajar siswa pada siklus II ini dapat dilihat pada tabel 6 dibawah ini:

Tabel 6 Nilai Hasil Belajar Siswa Siklus II

\begin{tabular}{|c|c|c|c|c|c|c|c|c|}
\hline \multirow[t]{2}{*}{ No } & \multirow[t]{2}{*}{ Nama Siswa } & \multicolumn{3}{|c|}{ SIKLUS HASIL } & \multirow[t]{2}{*}{ JUMLAH } & \multirow{2}{*}{$\begin{array}{l}\text { Rata- } \\
\text { rata }\end{array}$} & \multicolumn{2}{|c|}{ Ketuntasan } \\
\hline & & P1 & $\mathbf{P 2}$ & P3 & & & Ya & Tdk \\
\hline \multicolumn{3}{|c|}{ Jumlah } & & & \multicolumn{2}{|l|}{4535} & 15 & 3 \\
\hline \multicolumn{3}{|c|}{ Rata-rata } & & & \multicolumn{2}{|l|}{83,9} & & \\
\hline \multicolumn{5}{|c|}{ Persentase Ketuntasan } & & & 83,3 & 16,6 \\
\hline \multicolumn{5}{|c|}{ Kategori } & \multicolumn{4}{|c|}{ Hampir seluruhnya } \\
\hline
\end{tabular}

Berdasarkan tabel 6 di atas hasil belajar siswa pada siklus II ini meningkat dan lebih baik dari siklus I. Hal ini terlihat dari persentase ketuntasan yaitu 88,8\% dan rata-rata nilai 83,9.

Berdasarkan hasil evaluasi siklus II yang tercantum pada tabel 6 observasi hasil belajar siswa pada materi keliling dan luas bangun datar sederhana dapat disimpulkan sebagai berikut: 1) Dari 18 siswa yang memperoleh nilai 65 atau lebih banyak 15 orang dengan ketuntasan $83,3 \%$. 2) Siswa yang memperoleh nilai kurang dari 65 adalah sebanyak 3 orang dari 18 siswa atau tidak tuntas 16,6\%. 3) Dari data ketuntasan diperoleh nilai rata-rata 83,9\%.

Hasil refeksi menunjukkan: 1) Guru semakin baik dalam penerapan metode STAD hal ini terlihat dari lembar observasi kegiatan guru dan lembar observasi kemampuan berfikir kritis siswa. 3) Pemanfaatan waktu sudah efisien karena sebagian besar siswa telah memahami pembelajaran dengan metode STAD. 4) Hasil belajar siswa jauh lebih meningkat dari sebelumnya terlihat dari nilai rat-rata siswa mencapai 83,9\%. 4) Dari hasil belajar dan kemampuan berfikir kritis siswa pada siklus II, dapat dilihat bahwa penerapan metode STAD ternyata dapat meningkatkan kemampuan berfikir kritis siswa dalam pembelajaran keliling dan luas bangun datar sederhana. 
Hasil penelitian tindakan kelas dengan menggunakan pola dua siklus, dengan setiap siklus terdiri tiga kali pertemuan, ternyata dapat meningkatkan kemampuan berpikir kritis siswa dalam penelitian ini. Berdasarkan masalah yang paling krusial yang perlu dipecahkan yaitu kurangnya kemampuan berfikir kritis siswa pada materi keliling dan luas bangun datar sederhana di kelas IV SD Negeri 1 Bulakamba untuk mengatasi hal tersebut peneliti bersama guru kolaborator menggunkan metode Student Teams Achievment Divisions (STAD) untuk meningkatkan kemampuan berfikir kritis siswa serta menunjang kemajuan hasil belajar siswa.

Dari rekapitulasi di atas, maka nampaklah jelas bahwa metode Student Teams Achievement Divisions (STAD) dapat meningkatkan kemampuan berfikir kritis siswa dalam pembelajaran keliling dan luas bangun datar sederhana. Hal ini terlihat dari tabel 8 dimana kemampuan berfikir kritis siswa yang awalnya hanya $62,6 \%$ menjadi81,7\% berarti hampir seluruh siswa memahami materi keliling dan ;uas bangun datar sederhana. Ini berimpikasi terhadap hasil belajar siswa yang mana berdasarkan standar ketuntasan minimal yang hanya $65 \%$ dengan menerapkan metode STAD kemampuan siswa untuk dapat berfikir kritis terhadap materi keliling dna luas bangun datar sederhana mengalami peningkatan secara tidak langsung dari yang awalnya 55,5\% menjadi $83,3 \%$. Dari penjelasan tadi diharapkan guru dapat menggunakan metode STAD ini dalam pembelajaran yang menuntut siswa untuk dapat berfikir kritis, karena metode STAD memiliki kelibihan-kelebihan yang dapat menunjang dalam pengembangan pengetahuan siswa (kognitif) salah satunya berfikir kritis.

Adapun kelebihan-kelebihan metode STAD sebagai berikut: 1) Meningkatkan kecakapan individu. 2) Meningkatkan kecakapan kelompok. 3) Meningkatkan komitmen. 4 Menghilangkan prasangka buruk terhadap teman sebaya. 5) Tidak bersifat kompetitif 6) Tidak memiliki rasa dendam

Dengan hasil penelitian yang telah diperoleh dan di analisa, maka telah membuktikan bahwa metode Student Teams Achievment Divisions (STAD) dapat meningkatkan kemampuan berfikir kritis siswa dalam pembelajaran keliling dan luas bangun datar sederhana di kelas SD Negeri 1 Bulakamba, Kab. Brebes.

\section{Simpulan dan Saran}

Berdasarkan pembahasan pada siklus I dan siklus II dapat disimpulkan bahwa dengan menggunakan pembelajara tuntas dapat meningkatkan kemampuan siswa menyelesaikan soal cerita pada materi pecahan di kelas IV SD Negeri 1 Bulakamba. Peningkatan kemampuan siswa dalam menyelesaikan soal cerita dapat dilihat pada siklus I sebesar $57,7 \%$ dan meningkat pada siklus II menjadi $79,9 \%$ berdasarkan penjelasan ini maka kemampuan siswa menyelesaikan soal cerita dapat dikategorikan dari kurang aktif menjadi aktif. Sementara peningkatan hasil ujian siswa dapat dilihat dari hasil pada siklus I dengan persentase $55,5 \%$ dan meningkat pada siklus II menjadi $82,5 \%$ berdasarkan penjelasan ini maka hasil belajar daoat dikategorikan hampir seluruhnya siswa tuntas dalam pembelajran pemecahan. Berdasarkan hasil penelitian dan analisis data pembelajran tuntas pada materi pecahan dengan kelompok belajar, tutor sebaya maupun bimbingan terhadap siswa yang mengalami kesulitan dalam belajar yang diberikan pada setiap pembelajaran yang dilakukan guru terbukti dapat meningkatkan kemampuan siswa dalam menyelesaikan soal cerita pada materi pecahan di kelas IV SD Negeri 1 Bulakamba.

Berdasarkan kesimpulan tersebut mengacu pada masalah yang diteliti. Penulis perlu menyampaikan saran-saran sebagai berikut. 1) Guru disarankan menerapkan pembelajaran tuntas untuk mengatasi kesulitan siswa dalam menghadapi pembelajaran yang menuntut siswa untuk dapat memecahkan masalah baik sehari-hari maupun dalam model matematika. 2) 
Peran guru sangatlah penting dalam memberikan bimbingan yang disertai dengan pemberian motivasi, tutor sebaya, dan bimbingan per individu.

\section{Daftar Pustaka}

Discovery. Jurnal Euclid. Volume 3, No. 1, Juni 2019.

Amir, F. M. 2015. Proses Berpikir Kritis Siswa Sekolah Dasar dalam Memecahkan Berbentuk Soal Cerita Matematika Berdasarkan Gaya Belajar. Jurnal Moth Educator Nusantara. Tahun 2015, Nomor 02, Volume 01.

Daryanto. 1997. Kamus Besar Bahsa Indonesia. Surabaya: Apollo.

Esminarto, dkk. 2016. Implementasi Model STAD dalam Meningkatkan Hasil Belajar Siswa. Jurnal Riset dan Konseptual. Volume 1, Nomor 1, November 2016.

Gusniar. 2018. Penerapan Model Pembelajaran Kooperatif Tipe STAD dalam Meningkatkan Hasil Belajar pada Mata Pelajaran IPS Kelas IV SDN No. 2 Orgoamas II. Jurnal Kreatif Tadulako Online. Volume 2, No. 1, Mei 2018

Heruman. 2010. Model Pembelajaran Matematika. Bandung: PT. Remaja Rosdakarya.

lqbal, M., dan Setyo, G, N. 2004. Kumpulan Rumus Matematika. Jakarta: Pustaka Agung Harapan.

Isjoni. 2010. Cooperative Learning. Jakarta: PT. Grasindo.

Lie, A. 2008. Cooperative Learning. Jakarta: PT. Grasindo.

Muschla, J. A dan Robert, M, G. 2009. Pedoman Praktis Tugas-Tugas Matematika dengan Aplikasi Kehidupan Nyata Sehari-hari. Jakarta: PT. Macanan Jaya Cemerlang.

Mustaqim, B \& Astuti, A. 2008. Ayo Belajar Matematika Untuk SD / MI kelas IV. Jakarta: Pusat Perbukuan, Departemen Pendidikan Nasional.

Nurkancana, Wayan dan PPN. Sumartana. 1990. Evaluasi Hasil Belajar. Surabaya: Usaha Nasional.

Slavin, R. E. 2010. Cooperative Learning. Bandung: Nusa Media.

Sudjana, N. 2004. Penilaian Hasil Belajar Mengajar. Bandung: PT. Remaja Rosdakarya.

Sugiono. 2007. Metode Penelitian Pendidikan Pendekatan Kuantitatif dan Kualitatif. Bandung: CV. Alfabeta.

Sugiyono. 2013. Metode Penelitian Pendidikan Pendekatan Kuantitatif, Kualitatif, dan R\&D. Bandung: Alfabeta.

Suharsimi, A. 1998. Dasar-Dasar Evaluasi Pendidikan. Jakarta: Bina Aksara.

Suprijono, A. 2011. Cooperative Learning. Yogyakarta: Pustaka Belajar. 
Syah, M. 2010. Psikologi Pendidikan. Bandung: PT. Remaja Rosdakarya.

Wardhani, I. \& Wihardit, K. 2008. Penelitian Tindakan Kelas. Jakarta: Penerbit Universitas Terbuka. 